\title{
Accounting
}

\section{An empirical analysis of macroeconomic and bank-specific factors affecting profitability of Vietnam banks}

\author{
Thu-Trang Thi Doana and Toan Ngoc Bui ${ }^{*}$
}

${ }^{a}$ Faculty of Finance and Banking, Industrial University of Ho Chi Minh City (IUH), Vietnam

\begin{tabular}{l}
\hline C H R O N I C L E \\
\hline Article history: \\
Received May 152020 \\
Received in revised format May \\
162020 \\
Accepted July 62020 \\
Available online \\
July 142020 \\
\hline Keywords: \\
Bank-specific \\
Macroeconomic \\
Panel data \\
Return on assets \\
Vietnam
\end{tabular}

\section{A B S T R A C T}

This article analyzes the impact of macroeconomic and bank-specific factors affecting the profitability of Vietnam banks, which is an emerging economy with the banking industry considered to be young but plays a very important role for the development of the economy. The study data was collected during the period of 2013-2018. The Generalized Method of Moment (GMM) is used to estimate the study model to ensure that the results obtained are of high confidence. The study results show that the bank profitability was positively affected by macroeconomic (such as economic growth and inflation) and bank-specific factors (such as bank capital, bank size, and liquidity risk), which is an interesting finding in Vietnam. The results of this study are important for bank managers and researchers.

(C) 2020 by the authors; licensee Growing Science, Canada

\section{Introduction}

In recent years, Vietnam has actively renewed economic policies to better suit the context of international economic integration. This has boosted Vietnam's banking industry to thrive and become more and more suitable to the market economy. When integrating into the international economy, Vietnamese banking industry will be welcomed with great opportunities. However, the difficulties and challenges which Vietnamese banking industry faces are not small. In order to overcome these difficulties, the Vietnamese banking industry must constantly improve its operational efficiency. It can be said that the profitability is always one of the important criteria that the banks are interested in when they want to improve their operational capacity (Albertazzi \& Gambacorta, 2009). Since the profitability shows the bank's ability to endure the economic distress (Aburime, 2009). Moreover, the bank profitability also contributes significantly to stabilizing the financial system (Athanasoglou et al., 2008). In general, the profitability is the subject of much interest in the banking sector, this interest is suitable not only for bank managers but also for researchers. The bank profitability is often affected by the macroeconomic and bank-specific factors (Syafri, 2012; Hasanov et al., 2018). This result is also found in many empirical studies. However, most of these studies have not been consistent about the factors affecting the bank profitability. For Vietnam, this is an emerging country (Bui, 2020a), with a relatively young banking system (Nguyen et al., 2020), and especially a lack of empirical studies on this matter. Therefore, the consideration of factors affecting the bank profitability is an interesting and necessary study topic for Vietnam. With such urgency, the author will conduct this study, which focuses primarily on analyzing the impact of macroeconomic and bank-specific factors on the bank profitability. The results of this study promise to have important implications for the bank managers, as well as researchers.

* Corresponding author.

E-mail address: buingoctoan@iuh.edu.vn (T. N. Bui) 


\section{Literature review and hypothesis development}

\subsection{Bank-specific factors and bank profitability \\ - Structure of bank capital and bank profitability}

The structure of bank capital is a concept that reflects the bank's level of loans and equity. In terms of measurement, this index is usually measured by dividing total equity by total assets. Therefore, this index shows the bank's ability to withstand the financial distress. Not only that, the structure of bank capital also reflects the bank capital adequacy (Syafri, 2012; Abate \& Mesfin, 2019), and the financial health of the bank (Kawshala \& Panditharathna, 2017). Accordingly, when the bank's equity ratio increases, the financial health of the bank will be increased, the bank's tolerance to financial distress will be improved, This is an important factor promoting the bank profitability (Ben \& Goaied, 2008; Kosmidou, 2008). The positive impact of capital structure on bank profitability is also found in many empirical studies, such as Demirguc-Kunt and Huizinga (1999), Khrawish et al. (2008), San and Heng (2012), Syafri (2012), Shah and Khan (2017), Abate and Mesfin (2019). However, there exists some opinion that the capital structure may negatively impact the bank profitability, such as Gul et al. (2011) and Hoffmann (2011). This implies that if the equity ratio is too high, it can lead to the bank wasting capital and missing out on many business opportunities, which can reduce the bank profitability. In Vietnam, the capital structure of the bank is always closely monitored to ensure the safety of the banking industry. On the other hand, the banking industry in Vietnam has always played a leading role in providing the capital for the economy (Bui, 2019a; Nguyen et al., 2019). Therefore, to the extent permitted, the Vietnam banks often increase their capital mobilization and make the most of this capital to lend, which has contributed significantly to improving the bank profitability. Based on this basis, the author proposes the following:

$\mathrm{H}_{1}$ : Capital structure (CS) has a positive impact on bank profitability (ROA).

\section{- Bank size and bank profitability}

The bank size is often measured through its total assets (Demirguc-Kunt \& Huizinga, 1999; Athanasoglou et al., 2006, 2008). The large banks often have many advantages when operating in the market and also, they are also big advantages of these banks. Indeed, the large banks will easily attract a large number of customers, and can easily withstand the economy distress, therefore, the profitability will be improved. The positive impact of bank size on the bank profitability is also found in a number of empirical studies, such as: Athanasoglou et al. (2008), Nuriyeva (2014), Petria et al. (2015), and Djalilov and Piesse (2016). Therefore, the study hypothesis is proposed by the author as follows:

$\mathrm{H}_{2}$ : Bank size (BC) has a positive impact on bank profitability (ROA).

\section{- Liquidity risk and bank profitability}

The liquidity risk is usually measured by the ratio of total loans/deposits and short term funding. This index is high, which will reflect the high bank risks and vice versa. And also, this index also shows the difference between the main source of income from banks' loans and the costs that banks have to spend to raise capital (Shaha et al., 2018). Therefore, the banks that accept high levels of liquidity risk can achieve big profitability. In other words, the liquidity risk can have a positive impact on bank profitability. This impact is consistent with the statement of Khrawish et al. (2008), Gul et al. (2011), Hoffmann (2011), Syafri (2012), Ibe (2013), Rasul (2013). However, if the liquidity risk is too high, it may cause difficulties for banking operations and the profitability will decrease (Athanasoglou et al., 2006, 2008; Davydenko, 2010; Capraru \& Ihnatov, 2014; Petria et al., 2015; Roman \& Sargu, 2015; Djalilov \& Piesse, 2016). During the study period, the liquidity risk at the Vietnam banks is always well controlled, which has contributed significantly to helping the banking industry develop stably and profitability to be improved. Therefore, the author proposes the following study hypothesis:

$\mathrm{H}_{3}$ : Liquidity risk (LR) has a positive impact on bank profitability (ROA).

\subsection{Macroeconomic factors and bank profitability}

\section{- Economic growth and bank profitability}

The economic growth is an important macroeconomic index that reflects the increase in domestic economic operations and income (Nguyen \& Bui, 2019; Nguyen et al., 2019). Not only that, the economic growth also shows the prospects of the economy, therefore, it can have a significant impact on bank profitability. Accordingly, if the economy grows well, the banking industry will have many favorable conditions to operate and improve the profitability (Gul et al., 2011; Zeitun, 2012). Based on this basis, the proposed study hypothesis is as follows:

$\mathrm{H}_{4}$ : Economic growth (EG) has a positive impact on bank profitability (ROA).

\section{- Inflation and bank profitability}

The inflation is an important index representing macroeconomics (Bui, 2019b). And also, this index also reflects the level of business risk which the banking industry shall face. However, the moderate inflation can stimulate the development of economy 
as well as the banking industry, causing the bank profitability to increase. The positive impact of inflation on bank profitability is also found in empirical studies by Khrawish et al. (2008), Alper and Anbar (2011), San and Heng (2012). Therefore, the author proposes the following study hypothesis:

$\mathrm{H}_{5}$ : Inflation (INF) positively affects bank profitability (ROA).

\section{Methodology}

This article focuses on the impact of macroeconomic and bank-specific factors on bank profitability. For this purpose, the authors have collected the data in tabular form, from data sources of 26 commercial banks in Vietnam and data of the World Bank, in the period of 2013-2018. For the analytical method, the author has estimated the study model according to the Generalized Method of Moment (GMM). This method allows the author to control potential endogenous and regression hypotheses violated in the study model (Bui, 2020b, 2020c; Doan, 2020a, 2020b; Doan \& Bui, 2020). The study model is set up based on the results of previous studies and the study hypotheses that the author has proposed. Accordingly, the dependent variable representing bank profitability (ROA) is measured through the ratio of profit after tax/ total assets. The independent variables are measured through index representing macroeconomic and bank-specific factors. The indicators representing bankspecific factors include: bank capital (BC), bank size (BS), and liquidity risk (LR). In addition, economic growth (EG) and inflation (INF) are indicators representing macroeconomics. The study model proposed by the author has the following equation:

where:

$$
\mathrm{ROA}_{\mathrm{it}}=\beta_{0}+\beta_{1} \mathrm{BC}_{\mathrm{it}}+\beta_{2} \mathrm{BS}_{\mathrm{it}}+\beta_{3} \mathrm{LR}_{\mathrm{it}}+\beta_{4} \mathrm{EG}_{\mathrm{t}}+\beta_{5} \mathrm{INF}_{\mathrm{t}}+\varepsilon_{\mathrm{it}}
$$

Dependent variable: Bank profitability (ROA).

Independent variables:

Bank capital (BC): Total equity / Total assets;

Bank size (BS): Ln(Total assets);

Liquidity risk (LR): Total loans / Deposits and short term funding;

Economic growth (EG): Annual growth of gross domestic product;

Inflation (INF): Annual growth of consumer price index.

\section{Results}

Data of variables in study model are described in Table 1 as follows:

Table 1

Descriptive statistics

\begin{tabular}{lcccc}
\hline & Variable & Mean & Min & Max \\
\hline Bank profitability (ROA) & & 0.006 & 0.001 & 0.026 \\
Bank capital (BC) & 0.087 & 0.033 & 0.238 \\
Bank size (BS) & 14.078 & 13.167 & 15.118 \\
Liquidity risk (LR) & 0.666 & 0.265 & 1.095 \\
Economic growth (EG) & 0.064 & 0.054 & 0.071 \\
Inflation (INF) & 0.037 & 0.009 & 0.066 \\
\hline
\end{tabular}

Table 2 shows that the independent variables positively correlate with bank profitability (ROA), which is quite consistent with the study hypothesis proposed by the author.

Table 2

Correlation coefficients among variables

\begin{tabular}{lccccc}
\hline & ROA & BC & BS & LR & \\
\hline ROA & 1.000 & & & & \\
BC & 0.154 & 1.000 & & & \\
BS & 0.285 & -0.634 & 1.000 & 1.000 & \\
LR & 0.386 & 0.129 & 0.231 & 0.294 & \\
EG & 0.121 & -0.238 & 0.210 & -0.155 & \\
INF & 0.073 & 0.153 & -0.104 & -0.720 & \\
\hline
\end{tabular}

The author has conducted the F test and the Hausman test to determine the appropriate analytical method, the contents are presented in the following Table 3 . Table 3 shows that the $F$ test $(F(25,125)=11.40)$ is statistically significant at the $1 \%$ significance level. Meanwhile, the Hausman test (Chi2 $(5)=9.01)$ is not statistically significant. Therefore, the Random Effects Model (REM) analysis method will be more suitable than the remaining analysis methods. In other words, the author will test the study model based on the estimated results by the REM method. 
Table 3

Estimation of study model using Pooled OLS, FEM, REM methods

\begin{tabular}{|c|c|c|c|}
\hline \multicolumn{4}{|c|}{ Dependent Variable: Bank profitability (ROA) } \\
\hline ROA & Pooled OLS & FEM & REM \\
\hline Constant & $-0.104^{* * *}$ & $-0.217^{* * *}$ & $-0.142^{* * *}$ \\
\hline $\mathrm{BC}$ & $0.073^{* * *}$ & $0.130^{* * *}$ & $0.110^{* * *}$ \\
\hline BS & $0.006^{* * *}$ & $0.014^{* * *}$ & $0.008^{* * *}$ \\
\hline LR & $0.006^{* *}$ & $0.008^{* * *}$ & $0.007^{* * *}$ \\
\hline EG & $0.254^{* * *}$ & 0.132 & $0.238^{* * *}$ \\
\hline INF & $0.082^{* * *}$ & $0.063^{* * *}$ & $0.077^{* * *}$ \\
\hline R-squared & $34.37 \%$ & $53.52 \%$ & $52.58 \%$ \\
\hline Significance level & $\mathrm{F}(5,150)=15.71$ Prob $>\mathrm{F}=0.000^{* * *}$ & $\mathrm{~F}(5,125)=28.78$ Prob $>\mathrm{F}=0.000^{* * *}$ & Wald $\operatorname{chi} 2(5)=139.15$ Prob $>\operatorname{chi} 2=0.000^{* * *}$ \\
\hline F test & & $\mathrm{F}(25,125)=11.40$ Prob $>F=0.000^{* * *}$ & \\
\hline Hausman test & & $\operatorname{chi} 2(5)=9.01 \quad$ Prob $>$ chi $2=0.109$ & \\
\hline
\end{tabular}

Table 4

Test of study model

\begin{tabular}{|c|c|c|c|}
\hline \multicolumn{2}{|c|}{ Multicollinearity test } & \multirow{2}{*}{$\begin{array}{c}\text { Breusch and Pagan Lagrangian multiplier } \\
\text { test }\end{array}$} & \multirow{2}{*}{ Wooldridge test } \\
\hline Variable & VIF & & \\
\hline $\mathrm{BC}$ & 2.07 & \multirow{6}{*}{$\begin{array}{l}\text { chibar } 2(01)=131.71 \\
\text { Prob }>\text { chi2 }=0.000^{* * *}\end{array}$} & \multirow{6}{*}{$\begin{array}{l}\mathrm{F}(1,25)=20.886 \\
\text { Prob }>\mathrm{F}=0.000^{* * *}\end{array}$} \\
\hline $\mathrm{BS}$ & 2.02 & & \\
\hline LR & 1.38 & & \\
\hline EG & 2.37 & & \\
\hline INF & 2.10 & & \\
\hline \multicolumn{2}{|c|}{ Mean VIF $=1.99$} & & \\
\hline
\end{tabular}

Note: ${ }^{* * *}$ indicates significance at the $1 \%$ level.

Based on Table 4, we see that the multicollinearity is assessed as not serious. However, the study model has heteroscedasticity and autocorrelation at $1 \%$ significance level. This shows that the results of the study model estimated by REM method are no longer reliable. To overcome this, the author will conduct estimation of study model by GMM method.

Table 5

Estimation of study model by GMM method

\begin{tabular}{|c|c|c|}
\hline \multicolumn{3}{|l|}{ Dependent Variable: Bank profitability (ROA) } \\
\hline ROA & Coef. & $\mathbf{P}>|\mathbf{z}|$ \\
\hline Constant & $-0.082^{* * *}$ & 0.000 \\
\hline $\mathrm{BC}$ & $0.026^{*}$ & 0.052 \\
\hline BS & $0.004^{* * *}$ & 0.000 \\
\hline LR & $0.016^{* *}$ & 0.030 \\
\hline EG & $0.261^{* * *}$ & 0.000 \\
\hline INF & $0.039^{*}$ & 0.081 \\
\hline Significance level & \multicolumn{2}{|c|}{ Wald $\operatorname{chi} 2(4)=264.63$ Prob $>\operatorname{chi} 2=0.000^{* * *}$} \\
\hline Arellano-Bond test for $\mathrm{AR}(2)$ in first differences & \multicolumn{2}{|c|}{$z=-1.62 \operatorname{Pr}>z=0.106$} \\
\hline Sargan test & \multicolumn{2}{|c|}{$\operatorname{chi} 2(4)=7.00$ Prob $>$ chi $2=0.136$} \\
\hline
\end{tabular}

Note: ${ }^{*},{ }^{* *}$ and ${ }^{* * *}$ indicate significance at the $10 \%, 5 \%$ and $1 \%$ level, respectively.

The estimation results of the study model by GMM method appear to be suitable and meaningful at $1 \%$ (Table 5). Thus, the macroeconomic and bank-specific factors have a significant impact on bank profitability (ROA). Specifically, bank profitability (ROA) is positively affected by the bank-specific factors, such as: $\mathrm{BC}(\beta=0.026$, at the $10 \%$ significance level), $\mathrm{BS}(\beta=0.004$, at the $1 \%$ significance level), and LR $(\beta=0.016$, at the $5 \%$ significance level). And also, bank profitability (ROA) is also positively affected by macroeconomic factors, such as EG $(\beta=0.261$, at $1 \%$ significance level) and INF $(\beta=0.039$, at the $1 \%$ significance level). Therefore, the estimation results of the study model have the following equation:

\begin{tabular}{|c|c|c|c|c|}
\hline $\begin{array}{c}\text { Bank capital } \\
\text { (BC) }\end{array}$ & & \multicolumn{3}{|c|}{$\begin{array}{l}\text { Table } 6 \\
\text { Test results of study hypotheses }\end{array}$} \\
\hline Bank size & & No & Hypothesis & Result \\
\hline (BS) & & $\mathrm{H}_{1}$ & $\mathrm{BC} \Rightarrow \mathrm{ROA}$ & Accepted \\
\hline & & $\mathrm{H}_{2}$ & $\mathrm{BS} \Rightarrow \mathrm{ROA}$ & Accepted \\
\hline 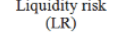 & $\begin{array}{l}\text { Bank profitability } \\
\text { (ROA) }\end{array}$ & $\mathrm{H}_{3}$ & $\mathrm{LR} \Rightarrow \mathrm{ROA}$ & Accepted \\
\hline & & $\mathrm{H}_{4}$ & $\mathrm{EG} \Rightarrow \mathrm{ROA}$ & Accepted \\
\hline $\begin{array}{l}\text { Economic growth } \\
(\mathrm{EG})\end{array}$ & & $\mathrm{H}_{5}$ & $\mathrm{INF} \Rightarrow \mathrm{ROA}$ & Accepted \\
\hline
\end{tabular}

Fig. 1. Study model results 
- Impact of bank capital on bank profitability: The study results show that bank capital (BC) had a positive impact on bank profitability (ROA). These results are consistent with the previous judgment of Demirguc-Kunt and Huizinga (1999), Khrawish et al. (2008), San and Heng (2012), Syafri (2012), Shah and Khan (2017), Abate and Mesfin (2019). This shows that the increase in the equity ratio will help the bank improve its capital adequacy and financial health, which will also help banks improve their financial distress, whereby the bank profitability will be improved. In Vietnam, the capital structure is one of the strictly controlled indicators of the banking industry, which has contributed significantly to improving the profitability and the stable development of the banking industry.

- Impact of bank size on bank profitability: The author has found positive impact of bank size (BS) on bank profitability (ROA). Accordingly, the size is one of the important advantages that help banks expand their market share, improve their competitiveness, and especially improve the profitability. The cumulative impact of bank size on bank profitability is also found in Athanasoglou et al. (2008), Nuriyeva (2014), Petria et al. (2015), Djalilov and Piesse (2016).

- Impact of liquidity risk on bank profitability: The results have shown that liquidity risk (LR) positively affects bank profitability (ROA). This impact is also consistent with previous study results of Khrawish et al. (2008), Gul et al. (2011), Hoffmann (2011), Syafri (2012), Ibe (2013), Rasul (2013). In Vietnam, the liquidity risk is always well controlled. With this characteristic, the banking industry in Vietnam has increased lending to the manufacturing sector. With that action, the liquidity risk has been well controlled, the amount of capital from the banking industry into the economy has always been improved, and bank profitability has also increased.

- Impact of economic growth on bank profitability: The authors have found positive impacts of economic growth (EG) on bank profitability (ROA). This shows that, when the economy is growing well, the banking industry will have many favorable conditions to improve the profitability. This result is also consistent with the previous judgment of Gul et al. (2011), Zeitun (2012).

- Impact of inflation on bank profitability: The results have shown that inflation (INF) positively affects bank profitability (ROA). This impact is also found in previous studies by Khrawish et al. (2008), Alper and Anbar (2011), San and Heng (2012). Accordingly, the moderate inflation may play an important role in improving the bank profitability.

\section{Conclusion}

This article focuses on analyzing the impact of macroeconomic and bank-specific factors on bank profitability in Vietnam, in the period of 2013-2018. Regarding the analytical method, the author uses the GMM method to ensure the estimation results of the study model with high confidence. The results have shown that the bank profitability are positively affected by macroeconomic factors (such as economic growth and inflation) and bank-specific factors (such as bank capital, bank size, and liquidity risk). Therefore, to improve the profitability, the bank managers need to pay attention to both macroeconomic and bank-specific factors. This is an important policy implication for the managers in banks. Not only that, the results of this study are also a reference for researchers in Vietnam as well as other countries in the world.

\section{References}

Abate, T.W., \& Mesfin, E.A. (2019). Factors affecting profitability of commercial banks in Ethiopia. International Journal of Research and Analytical Reviews, 6(1), 881-891.

Aburime, T. (2009). Impact of political affiliation on bank profitability in Nigeria. African Journal of Accounting, Economics, Finance and Banking Research, 4(4), 61-75.

Albertazzi, U., \& Gambacorta, L. (2009). Bank profitability and the business cycle. Journal of Financial Stability, 5, 393-409.

Alper, D., \& Anbar, A. (2011). Bank specific and macroeconomic determinants of commercial bank profitability: Empirical evidence from Turkey. Business and Economics Research Journal, 2(2), 139-152.

Athanasoglou, P., Delis, M., \& Staikouras, C. (2006). Determinants of Bank Profitability in the South Eastern European Region. Working Papers 47. Athens: Bank of Greece.

Athanasoglou, P., Brissimis, S., \& Delis, M. (2008). Bank-specific, industry-specific and macroeconomic determinants of bank profitability. Journal of International Financial Markets, Institutions and Money, 18(2), 121-136.

Ben, N.S. \& Goaied, M. (2008). The determinants of commercial bank interest margin and profitability: evidence from Tunisia. Frontiers in Finance and Economics, 5(1), 106-130.

Bui, T.N. (2019a). The Role of Financial Development in the Vietnam Economy. WSEAS Transactions on Business and Economics, $16,471-476$.

Bui, T.N. (2019b). Inflation and stock index: evidence from Vietnam. Journal of Management Information and Decision Sciences, 22(4), 408-414.

Bui, T.N. (2020a). Stock holding decisions of foreign investors in emerging stock markets: A case study in Vietnam. Management Science Letters, 10(3), 625-630. 
Bui, T.N. (2020b). How do financial leverage and supply chain finance influence firm performance? Evidence from construction sector. Uncertain Supply Chain Management, 8(2), 285-290.

Bui, T.N. (2020c). Supply chain finance, financial development and profitability of real estate firms in Vietnam. Uncertain Supply Chain Management, 8(1), 37-42.

Capraru, B., \& Ihnatov, I. (2014). Banks' profitability in selected central and eastern European countries. Procedia Economics and Finance, 16, 587-91.

Davydenko, A. (2010). Determinants of bank profitability in Ukraine. Undergraduate Economic Review, 7(2), 1-30.

Demirguc-Kunt, A., \& Huizinga, H. (1999). Determinants of commercial bank interest margins and profitability: some international evidence. The World Bank economic review, 13(2), 379-408.

Djalilov, K., \& Piesse, J. (2016). Determinants of bank profitability in transition countries: What matters most?. Research in International Business and Finance, 38, 69-82.

Doan, T.T.T. (2020a). Profitability of real estate firms: Evidence using GMM estimation. Management Science Letters, 10(2), 327332.

Doan, T.T.T. (2020b). Financing decision and firm performance: Evidence from an emerging country. Management Science Letters, $10(4), 849-854$

Doan, T.T.T., \& Bui, T.N. (2020). Nonlinear impact of supply chain finance on the performance of seafood firms: A case study from Vietnam. Uncertain Supply Chain Management, 8(2), 267-272.

Gul, S., Irshad, F., \& Zaman, K. (2011). Factors affecting bank profitability in Pakistan. The Romanian Economic Journal, $39,61-87$.

Hasanov, F.J., Bayramli, N., \& Al-Musehel, N. (2018). Bank-specific and macroeconomic determinants of bank profitability: Evidence from an oil-dependent economy. International Journal of Financial Studies, 6(3), 1-21.

Hoffmann, P.S. (2011). Determinants of the profitability of the US banking industry. International Journal of Business and Social Science, 2(22), 255-269.

Ibe, S.O. (2013). The impact of liquidity management on the profitability of banks in Nigeria. Journal of Finance and Bank Management, 1(1), 37-48.

Kawshala, H., \& Panditharathna, K. (2017). The factors effecting on bank profitability. International Journal of Scientific and Research Publications, 7(2), 212-216.

Khrawish, H., Al-Abadi, M., \& Hejazi, M. (2008). Determinants of commercial bank interest Rate Margins: Evidence from Jordan. Jordan Journal of Business Administration, 4(4), 485-502.

Kosmidou, K. (2008). The determinants of banks' profits in Greece during the period of EU financial integration. Journal of economic literature, 34(3), 146-159.

Nguyen, M.L.T., \& Bui, T.N. (2019). Stock market, real estate market, and economic growth: an ARDL approach. Investment Management and Financial Innovations, 16(4), 290-302.

Nguyen, M.L.T., Bui, T.N., \& Nguyen, T.Q. (2019). Relationships between real estate markets and economic growth in Vietnam. Journal of Asian Finance, Economics and Business, 6(1), 121-128.

Nguyen, M.L.T., Pham, T.T.X, \& Bui, T.N. (2020). Causal relationship between banking system development and real estate market. Management Science Letters, 10(1), 41-52.

Nuriyeva, Z. (2014). Factors Affecting the Profitability of Azerbaijan Banking System. Master's dissertation, Eastern Mediterranean University, Gazima gusa, North Cyprus, Turkey.

Petria, N., Capraru, B., \& Ihnatov, I. (2015). Determinants of banks' profitability: Evidence from EU 27 banking systems. Procedia Economics and Finance, 20, 518-24.

Rasul, L. (2013). Impact of Liquidity on Islamic Banks’ Profitability: Evidence from Bangladesh. ECONOMICA, 9(2), 23-36.

Roman, A., \& Sargu, A.C. (2015). The impact of bank-specific factors on the commercial banks liquidity: Empirical evidence from CEE countries. Procedia Economics and Finance, 20, 571-79.

San, O.T., \& Heng, T.B. (2012). Factors affecting the profitability of Malaysian commercial banks. African Journal of Business Management, 7(8), 649-660.

Shah, M.H., \& Khan, S. (2017). Factors effecting commercial banks profitability in Pakistan. Journal of Business and Tourism, 3(1), $1-12$.

Shaha, S.Q.A., Khana, I., Shah, S.S.A., \& Tahir, M. (2018). Factors affecting liquidity of banks: Empirical evidence from the banking sector of Pakistan. Colombo Business Journal, 9(1), 1-18.

Syafri (2012). Factors Affecting Bank Profitability in Indonesia. The 2012 International Conference on Business and Management, 6 - 7 September 2012, Phuket - Thailand.

Zeitun, R. (2012). Determinants of Islamic and conventional banks performance in GCC countries using panel data analysis. Global Economy and Finance Journal, 5(1), 53-72.

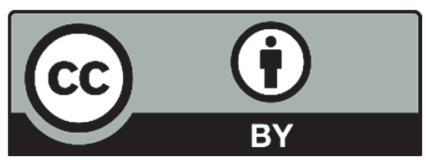

(C) 2020 by the authors; licensee Growing Science, Canada. This is an open access article distributed under the terms and conditions of the Creative Commons Attribution (CC-BY) license (http://creativecommons.org/licenses/by/4.0/). 